\title{
建築基準法での限界耐力計算法における表層地盤の取り扱い
}

\author{
小山 信*

\section{Consideration of subsurface layer to evaluate site amplification effect in the response and limit strength calculation design method, the building standard law}

\begin{abstract}
Shin Koyama*
ABSTRACT

Buildings in Japan must be designed and constructed according to Building Standard Law, the Enforcement Order and the Notification by Ministry of Construction and the Ministry of Land, Infrastructure and Transport notification. The buildings in our country are suffered the extensive damages cause by earthquake, typhoon, and fire, etc. Then, earthquake is adopted as one of forces/loads that should be endured by the buildings. Through these valuable experiences, we learned that the ground condition strongly influences earthquake ground motion and earthquake damage. By conventional Allowable stress design method, seismic design force level is defined taking into account the surface geological condition at construction site. In addition, by the Response and Limit Strength Calculation design method newly adopted for performance-based design concept by the revised Building Standard Law in June, 1998 the seismic force is defined at engineering bedrock as an acceleration response spectrum corresponded to the seismic activity in a region concerned with the site amplification effect by subsurface layers and soil-structure interaction effect. In this paper, I would like to introduce the consideration of subsurface layers to evaluate site amplification effect under the Building Standard Law and relating regulation especially with relation to the Response and Limit Strength Calculation design method.
\end{abstract}

Key words: building standard law, enforcement order, notification, subsurface layer, site amplification effect

\section{1. はじめに}

我が国の建築物は，過去において地震，台風，火災等 により幾多と無く甚大な被害を受けてきた。このような 災害等に対して建築物の安全を確保し, 質の向上を図つ ていくことは, 国民の生命, 健康および財産の保護, な らびに公共の福祉を増進する観点から重要である。日本 の建築物（ここで用いる「建築物」とは，建築基準法第 二条第一項に用語が定義されているものである。）は, 建築基準法および建築基準法に基づく建設省・国土交通 省告示，等建築基準法関係規定に従つて設計・建設され る。昭和 25 年の制定当初から, 建築基準法（以下, 「基 準法」と呼ぶ。）では第一条に「この法律は，建築物の

2006 年 3 月 17 日原稿受付; 2006 年 5 月 2 日受理

* 独建築研究所

干 305-0802 茨城県つくば市立原 1 番地

(C)2006 SEGJ
敷地，構造，設備及び用途に関する最低の基準を定め て，国民の生命，健康及び財産の保護を図り，もつて公 共の福祉の増進に資することを目的とする。」と述べら れ，全ての建築物が遵守すべき最低の基準が規定されて いる（国土交通省 HP，2005a）。そして建築物が耐える べき各種の荷重および外力の一つとして, 地震が採用さ れている。

これまでの貴重な経験を通じて, 地震動特性や地震被 害は建築物の立つ表層地盤条件の影響を強く受けること を学んでいる。建築基準法関係規定においても, 従来か らの許容応力度等計算で建築物に作用する設計用地震力 を設定する際には，表層地盤の影響を取り入れるように なっている。さらに平成 10 年 6 月に公布された改正建 Manuscript received March 17, 2006; Accepted May 2, 2006.

* Building Research Institute

Tatehara-1, Tsukuba, Ibaraki 305-0802, Japan 
築基準法で新たに採用された限界耐力計算は, 地震荷重 を地震動で既定することとし, その地震動特性を工学的 基盤における当該地域の地震活動度に対応した加速度応 答スペクトルとして代表させ，その加速度応答スペクト ルに各建設地の地盤デー夕に基づき算定した表層地盤の 増幅特性を掛け合わせて, さらに可能な場合には地盤と 基礎，上部構造相互間の動的相互作用効果を考慮して上 部構造への入力位置における評価用地震動を求めること になっている。従って, 許容応力度等計算と比較して, 地盤条件の影響をより精緻に評価することが可能となつ ている。

ここでは, 表層地盤の取り扱いに関わる建築基準法関 係規定を紹介するとともに，限界耐力計算についてその 計算方法と留意点・課題について述べる。

\section{2. 建築基準法関係規定における構造規定}

安全な建築物を造るために，基準法第二十条において 建築物が耐えるべき各種の荷重および外力として自重, 積載荷重, 積雪, 風圧, 土圧, 地震その他の振動および 衝撃が示されている。それらの荷重・外力に対して安全 な構造とするために，基準法第二十条第一号に基づく構 造方法の規定（主として仕様による規定となっており， 「仕様規定」と呼ばれる）と，基準法第二十条第二号に 基づく構造計算の規定が示されている。これらを満足す るために従うべき具体的な技術基準が，建築基準法施行 令（以下，「施行令」と呼ぶ。）の第三章構造強度（第三 十六条～第九十九条）の各所に規定されている（国土交 通省 HP，2005b)。この技術的基準の適用が第一節総則 の施行令第三十六条（構造方法に関する技術的基準）に 定められ，基準法第二十条第一号に規定されている技術 的基準（仕様規定）が施行令第三章第一節（総則）から 第七節の二であること，ならびに構造種別，規模等に応 じて建築物がよらなければならない構造方法が規定され ている。そして施行令第三十六条の二で，構造設計の原 則が規定されている。施行令三十六条による建築物の種 類別に適用できる構造関係規定は，表 1,2 のとおりと なっている（飯場，2001）。一部については後述する が，構造方法 2〜 4 の計算方法において，建築物に作用 する外力のひとつとして地震力を採用している。

構造計算に直接関わる規定は, 施行令第八節構造計算 （第八十一条〜第九十九条）である。ここでは，構造計 算において確かめるべき事項，建築物の構造種別，高さ 等に応じた各種構造計算方法, 荷重および外力, 材料の 許容応力度, 材料強度を定めている。

施行令第八十一条第 1 項において，超高層建築物を 除く建築物の構造計算は, 許容応力度等計算または限界 耐力計算によらなければならないと規定している。なお これらと同等以上に安全を確かめることができるものと して国土交通大臣が定める基準に従った構造計算による 場合は除外される。また超高層建築物（高さ $60 \mathrm{~m}$ を越
表 1 建築物で選択できる構造規程（飯場，2001）

\begin{tabular}{l|l}
\hline \multicolumn{1}{c|}{ 対象となる建築物 } & \multicolumn{1}{|c}{ 選択できる構造規程 } \\
\hline $\begin{array}{l}\text { 構造計算が義務となっていな } \\
\text { い建築物（いわゆる } 4 \text { 号建 } \\
\text { 築物等 })\end{array}$ & $\begin{array}{l}\text { 構造方法 } 1, \text { 構造方法 } 3, \text { 構 } \\
\text { 方法 } 4 \text { のいずれか }\end{array}$ \\
\hline $\begin{array}{l}\text { 上記を除き建築物高さが } 60 \\
\mathrm{~m} \text { 以下の建築物 }\end{array}$ & 構造方法 2, 構造方法 3, 構 \\
造方法 4 のいずれか \\
$\begin{array}{l}\text { 建築物の高さが } 60 \mathrm{~m} \text { を超え } \\
\text { る建築物 }\end{array}$ \\
\hline
\end{tabular}

表 2 構造方法別に適用される構造規程（飯場，2001）

\begin{tabular}{l|l}
\hline & \multicolumn{1}{|c}{ 適応される構造規程 } \\
\hline 構造方法 1 & 仕様規程に適合 \\
\hline 構造方法 2 & $\begin{array}{l}\text { 仕様規程 }+ \text { 許容応力度等計算 } \\
\text { または } \\
\text { 仕様規程 +許容応力度等計算同等の構造計算 }\end{array}$ \\
\hline 構造方法 3 & $\begin{array}{l}\text { 而久性等関係規程 +限界耐力計算 } \\
\text { または } \\
\text { 耐久性等関係規程 +限界耐力計算同等の構造計算 }\end{array}$ \\
\hline 構造方法 4 4 & $\begin{array}{l}\text { 耐久性等関係規程＋超高層建築物等の構造計算 } \\
\text { (大臣認定) }\end{array}$ \\
\hline
\end{tabular}

える建築物）は，施行令八十二条の二で荷重および外力 によって建築物の各部分に生ずる力および変形を連続的 に把握することにより，建築物が構造耐力上安全である ことを確かめることができるものとして国土交通大臣が 定める基準に従った構造計算によらねばならないことが 規定されている。

施行令第八十一条第 1 項において構造算法として規 定されている許容応力度等計算と限界耐力計算は，それ ぞれ施行令第八十二条から八十二条の五と八十二条の六 で規定されている。

\section{3. 許容応力度等計算}

許容応力度等計算では, 以下のことが要求される（国 土交通省住宅局建築指導課ほか，2001）。

(1)荷重および外力ならびに荷重の組み合わせを考慮し, 建築物の構造上主要な部分に生ずる長・短期の各応力 度が各材料の許容応力度を越えないことを確かめる。

(2)国土交通大臣が定める場合においては，変形，振動に よる支障が起こらないことを確かめる。

(3)屋根ふき材等が風圧に対して安全であることを確かめ る。

(4)地震によって各階に生ずる相対的な水平変位を当該各 階の高さで除した値である層間変形角を計算して，そ れが $1 / 200$ 以下であることを確かめる。

(5)高さ $31 \mathrm{~m}$ 以下の特定建築物については, 各階の剛性 率および偏心率を計算し，それぞれ 0.6 以上および 
0.15以下であることを確かめる。

(6)高さ $31 \mathrm{~m}$ を超える特定建築物については，荷重に対 する抵抗がない状態の建築物骨組みにおいて，各階の 柱，および壁に生じている軸力とせん断力の水平成分 の総和である保有水平耐力が，建築物に要求すべき最 終的な水平方向の抵抗力である必要保有水平耐力以上 であることを確かめる。

ここで建築物に作用する外力として考慮すべき荷重お よび外力のひとつとして，施行令第八十三条において地 震力を採用し, その地震力は施行令第八十八条によって 規定される。施行令第八十八条によると, 建物の地上部 分の地震力については, 式 (1)によって計算される当該 建築物の各部分の高さにおける地震層せん断力係数（あ る層に作用するせん断力をその層以上の固定荷重と積載 荷重の総和で除した值。） $C_{i}$ を乗じて計算される。

$$
C_{i}=Z R_{t} A_{i} C_{0}
$$

ここで, $Z$ は地震地域係数で, その地方における過去の 地震の記録に基づく震害の程度及び地震活動の状況その 他地震の性状に応じて 1.0 か 0.7 までの範囲内において 国土交通大臣が定める数值， $R_{t}$ は振動特性係数で, 建 築物の振動特性を表すものとして建築物の弾性域におけ る固有周期及び地盤の種類に応じて国土交通大臣が定め る方法により算出した数值, $A_{i}$ は地震層せん断力の建 築物の高さ方向の分布を表す係数で，国土交通大臣が定 める方法により算出した数值, $C_{0}$ は標準せん断力係数 である。 $R_{t}$ を算出する際に考慮される地盤の種別なら びに地盤の種別に基づいた $R_{t}$ の形状は，建設省告示第 千七百九十三号第二において規定される（国土交通省 HP, 2005c)。それには地盤の種別は第一種地盤から第 三種地盤まであり，それらは表 3 のように分類される。 $R_{t}$ の形状は, この地盤種別により式 $(2) \sim(4)$ のように 算出される。

$$
\begin{array}{ll}
T<T_{c} \text { の場合 } & R_{t}=1 \\
T_{c} \leq T<2 T_{c} \text { の場合 } & R_{t}=1-0.2\left(T / T_{c}-1\right)^{2} \\
& \\
2 T_{c} \leq T \text { の場合 } & R_{t}=1.6 T_{c} / T
\end{array}
$$

ここで $T, T_{c}$ は，建築物の設計用一次固有周期と地盤の
種別に応じて表 3 に掲げる数值である。この形状は, 図 1 に示すように短周期領域では加速度振幅一定, 長 周期領域では地盤種別に応じた値を取り速度振幅一定, それらの中間の周期領域で加速度と速度を二次曲線で滑 らかに接続した形状である。ただし，特別の調査又は研 究の結果に基づき建築物の振動特性を表す数值が式 (2) 〜 (4) によって算出した数值を下回ることが確かめられ た場合においては, 当該調査又は研究の結果に基づく数 值（この数值が同表の式によって算出した数值に四分の 三を乗じた数值に満たないときは，当該数）まで減じた ものとすることが認められている。標準せん断力係数 $C_{0}$ は，施行令八十八条第 2 項によって 0.2 以上とするこ と，また第 3 項によって施行令第八十二条の四第二号 の規定により必要保有水平耐力を計算する場合において は，前項の規定にかかわらず，標準せん断力係数は, 1.0 以上としなければならないと規定され，それぞれは 中程度の地震力（震度 5 強程度を想定）と大地震時の 地震力（震度 6 強〜 7 程度を想定）の 2 つレベルに対応 している。一方, 建築物の地下部分の各部分に作用する 地震力は，第 4 項に示されるように地盤種別など地盤 条件によらず一定である。

\begin{tabular}{|c|c|c|}
\hline 地盤種別 & 地 盤 の 特 性 & $T c$ \\
\hline 第一種地盤 & $\begin{array}{l}\text { 岩盤, 硬質砂れき層その他主として第三紀以前の地層によって構成されているもの又は地盤周期等についての調 } \\
\text { 查若しくは研究の結果に基づき, これと同程度の地盤周期を有すると認められるもの }\end{array}$ & 0.4 \\
\hline 第二種地盤 & 第一種地盤及び第三種地盤以外のもの & 0.6 \\
\hline 第三種地盤 & 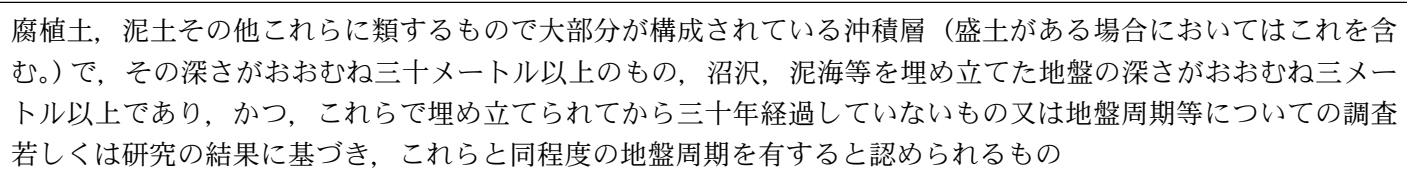 & 0.8 \\
\hline
\end{tabular}

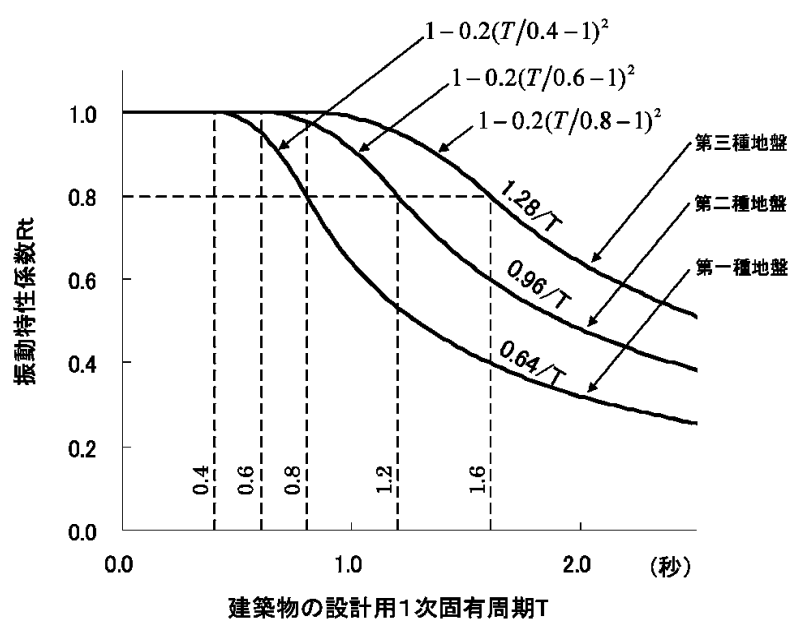

図 1 振動特性係数 $R_{t}$

表 3 昭和55年建設省告示第千七百九十三号第一で定める地盤種別（国土交通省 HP, 2005c） 


\section{4. 限界耐力計算法}

\section{4. $1 G_{S}$ の計算の概要}

施行令第八十二条の六で定められる限界耐力計算は, 平成12年の施行令改正において従来の許容応力度等計 算と並立する形で設けられた構造計算である。

限界耐力計算の基本的な考元方は，荷重・外力による 建築物の挙動を把握し，それに基づき算定される応答値 と要求性能から求まる限界值を比較して, 応答值が限界 值を超えないことを確かめるというものである。そのた め, 仕椂規定への適合を前提とする許容応力度等計算と 異なり，施行令第三十六条第 2 項に規定される耐久 性, 品質施行等に関する構造計算では確認することがで きない規定以外の仕様規定の適用が不用とされている。

限界耐力計算では, 中程度および最大級の地震により 建築物の各階に作用する地震力は, 施行令八十二条の六 第三号及び五号の八で規定される。ここでの算定では, 表層地盤（工学的基盤［地下深部にあって十分な層厚と 剛性を有し，せん断波速度が約 400 メートル毎秒以上の 地盤をいう。以下同じ］上面以浅の地盤をいう。以下同 じ）の種類に応じて国土交通大臣が定める方法により算 出した, 加速度の増幅率を表す数值 $G_{S}$ が採用されてい る。この $G_{S}$ を算出する方法は, 建設省告示第千四百五 十七号第七において規定されている（国土交通省 HP, 2005d)。G $G_{S}$ の形状とレベルを決める表層地盤の一次 ・ 二次卓越周期 $T_{1}, T_{2}$ と, それ対する増幅率 $G_{S 1}, G_{S 2}$ は，式(5)〜 (10)により算定される。

$$
\begin{aligned}
T_{1} & =\frac{4\left(\Sigma \mathrm{H}_{\mathrm{i}}\right)^{2}}{\sum \sqrt{G_{i} / \rho_{i}} H_{i}} \\
T_{2} & =\frac{T_{1}}{3} \\
G_{S 1} & =\frac{1}{1.57 h+\alpha} \\
G_{S 2} & =\frac{1}{4.71 h+\alpha}
\end{aligned}
$$

ここで,

$H_{i}$ 地盤調査によって求められた地盤の各層の 層厚（単位メートル）

$G_{i} \quad$ 地震時に生じる地盤のせん断ひずみに応じて 土質ごとに定まる地盤の各層のせん断剛性

$\alpha$ 次の式によって計算した波動インピーダンス 比，ただし， $\rho_{B}, V_{B}$ は，工学的基盤の密度 とせん断波速度

$$
\alpha=\frac{\Sigma \sqrt{G_{i} / \rho_{i}} H_{i} \cdot \Sigma \rho_{i} H_{i}}{\left(\Sigma H_{i}\right)^{2}} \cdot \frac{1}{\rho_{B} V_{B}}
$$

$h \quad$ 地震時の表層地盤によるエネルギー吸収の程 度を表すものとして次の式によって計算した 数值 $(0.05$ 未満となる場合には， 0.05 とす
る。)

$$
h=0.8 \frac{\Sigma h_{i} \cdot w_{i}}{\Sigma w_{i}}
$$

$h_{i}$ 表層地盤のせん断ひずみ及び土質に応じて地 震時に生ずる，表層地盤の各層の減衰定数

$w_{i}$ 地震時における表層地盤の各層の最大弾性ひ ずみエネルギーを表す数值

これらの式では, 多層からなる表層地盤（工学的基盤を 含む）は各層が水平方向に一様な水平成層構造であると 仮定し，その表層地盤を等価な 2 層地盤に置換え，そ れに一次元波動理論に基づいた方法を用いて評価してい る（国土交通省建築研究所，2001）。更に $G_{S}$ は，建築 物と表層地盤との相互作用に関する係数 $\beta$ を乗じるこ とができるものとされている。この $\beta$ は，地盤調査に よって求められた建築物地下部分の底面および側面にお ける水平地盤ばね定数や上記 $G_{S}$ 等にもとづいて計算さ れ，下限值 0.75 まで低減することができる。以上の計算 方法を適用する場合には，地盤の層序，各層の単位堆積 重量, せ九断波速度等の地盤定数が必須なことから, 当 該地盤における地盤情報が整つているか地盤調查を行う 必要が生じる。一方で上記のような計算作業が困難な場 合は, 昭和五十五年建設省告示第千七百九十三号第二に 揭げられる地盤種別によって $G_{S}$ を計算することができ る簡略法も, 同告示に示されている。図 2 に示す本簡 略法で求まる $G_{S}$ の短周期側と長周期側の係数一定のレ ベルは, 許容応力度等設計法で用いられる $C_{0}$ に相当す る地震動を解放工学的基盤（表層地盤による影響を受け ないものとした工学的基盤）における加速度応答スペク トルで割ることで得られている。

$G_{S}$ を求めるための地震動は, 工学的基盤で与えられ

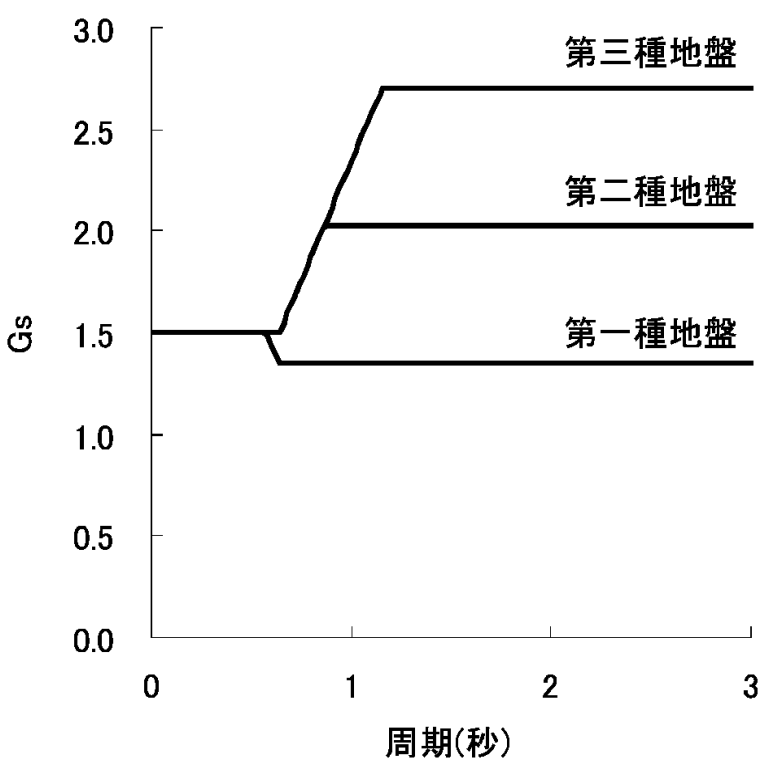

図 2 地盤種別によって定まる $G_{S}$ 
る必要がある。この地震動は, 許容応力度等設計法の場 合のように施行令ならびに告示に直接明示はされていな いため, 図 3 に示す超高層建築物の構造耐力上の安全 性を確かめるための構造計算の基準を定める建設省告示 第千四百六十一号に規定されている，解放工学的基盤に おける加速度応答スペクトル（以下，標準加速度応答ス ペクトル）を援用することになる。この標準加速度応答 スペクトルの形状は，短周期側を加速度振幅一定，長周 期側を速度振幅一定として表される。なお，極短周期領 域は加速度応答スペクトルとしての形状を持たせる必要

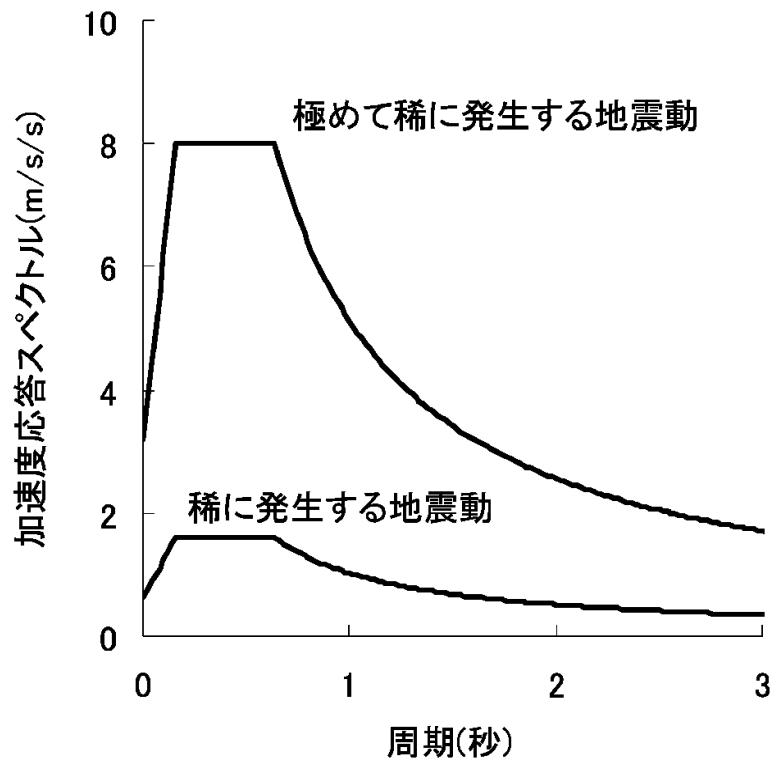

図 3 解放工学的基盤における加速度応答スペクトル
から，周期ゼロ秒で入力の最大加速度值とされている。 ここで最大加速度值は, 最大スペクトルレベルの 2.5 分 の 1 として設定されているが，この数字は日本建築学 会の荷重指針（日本建築学会, 1993）やATC-3（Applied Technology Council, 1978）における有効加速度振 幅にも対応しているものである (国土交通省建築研究所, 2001)。標準加速度応答スペクトルの加速度・速度振幅 一定のレベルは, 既往の地震カレベルとの連続性を考慮 して建設省告示第千七百九十三号第二において規定され る第二種地盤における $R_{t}$ を地震荷重と同等のものとし て規定されている。石山（1987）により示された層せ 几断力係数と地震動応答スペクトルとの関係に関する提 案に基づいて, 図 4 に示すように, 最大級の地震レべ ルに対しては加速度応答スペクトルレベルは $9.8(\mathrm{~m} / \mathrm{s} /$ s) $\times 1.23 \div 1.5=8(\mathrm{~m} / \mathrm{s} / \mathrm{s})$, 速度レベルは $1.5(\mathrm{~m} / \mathrm{s}) \times$ $1.1 \div 2.0=0.8(\mathrm{~m} / \mathrm{s})$ となっている。ここで, $9.8(\mathrm{~m} / \mathrm{s} /$ $\mathrm{s}), 1.5(\mathrm{~m} / \mathrm{s})$ は, 標準せん断力係数 $(\mathrm{C} 0=1.0)$ と重 力加速度 $\mathrm{g}$ を掛け合わせたスペクトルの加速度振幅一 定，速度振幅一定のレベル，乗数1.23, 1.1 1 多質点系の ベースシアを同じ固有周期を持つ 1 質点系のそれに変 換する係数, 除数 $1.5,2.0$ は第二種地盤での加速度, 速 度スペクトルの平均的地盤増幅率として設定したもので ある。

\section{4. $2 G_{S}$ の収斂計算}

$G_{S}$ の算定において，考慮する地震動レベルと土質に 応じた表層地盤のせん断ひずみレベルの影響を受ける $h$ およびを $\alpha$ 定めることになっている。せん断ひずみを 求めるためには, 各層の相対変位が必要となる。その相

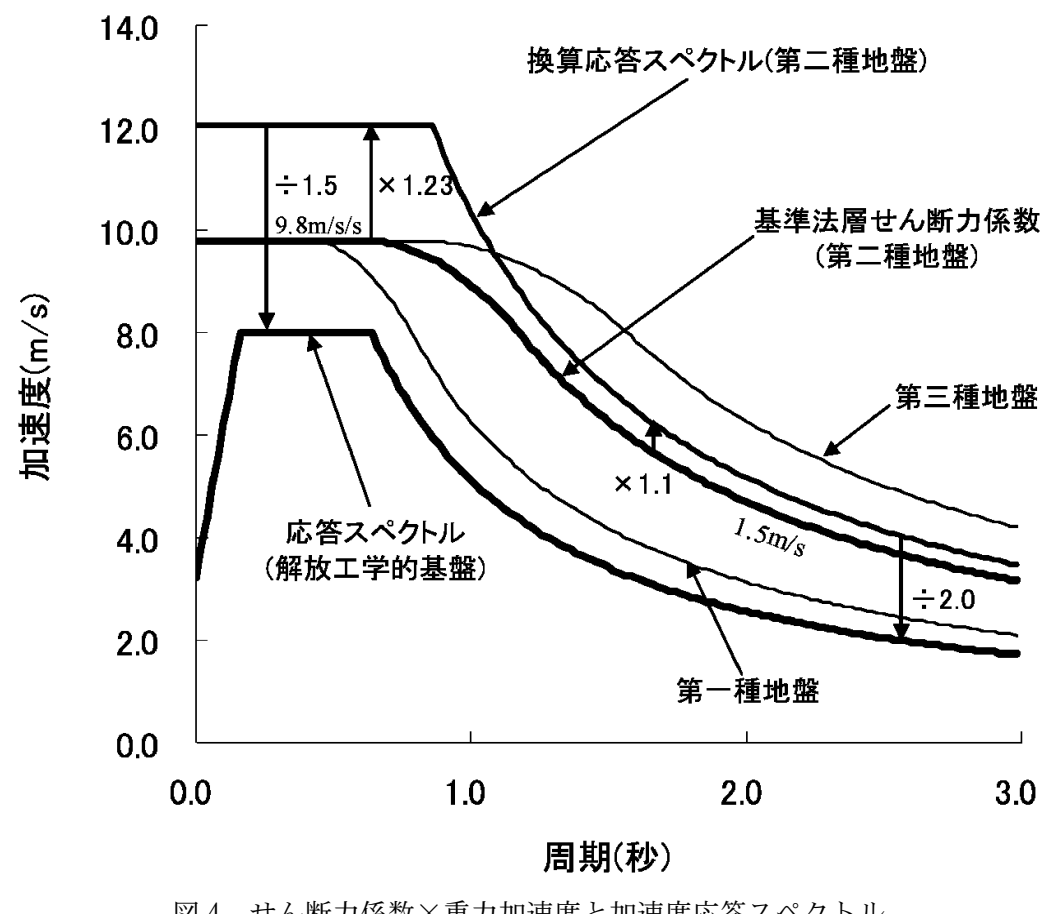

図 4 せ九断力係数 $\times$ 重力加速度と加速度応答スペクトル 
対変位を求める方法については建築基準法関係規定では 規定されておらず，任意の計算手法の適用が許容されて いる。例えば，三浦ほか（2001）は，応答スペクトル 法を用いて表層地盤の 1 次の卓越周期とモード形，そ れと地表面および工学的基盤面の変位を求めている。国 土交通省住宅局建築指導課ほか（2001）は，三浦ほか （2001）の方法を参考に，卓越周期とモード形の手計算 が可能な重力式を用いた方法を提案している。これらの 計算方法では, 地盤の各層のせん断剛性 $G_{i}$ と減衰定数 $h_{i}$ のひずみ依存性を考慮するために, SHAKE 等が採用 する手法と同様な繰り返し計算（収斂計算）が必要とな る。その行程は, 図 5 のように示される。

\section{3 限界耐力計算法の課題}

限界耐力計算の導入により, 建築物の建つ当該地盤の 震動特性を許容応力度等設計法より詳細に考慮すること が可能となった。しかしながら，遍く建築構造設計者が 利用できることが前提であったことから，パソコン等を 使用せずに手計算でも使えるように単純化することが必 要となり, 多層からなる表層地盤は等価な 2 層地盤に 単純化して計算する方法が採用されるとともに，地震動 レベルと土質に応じて定まる非線形特性も 2 種類に限 定された。実際の地盤震動特性は, 日本建築センターの 設計用入力地震動作成手法指針案（日本建築センター,

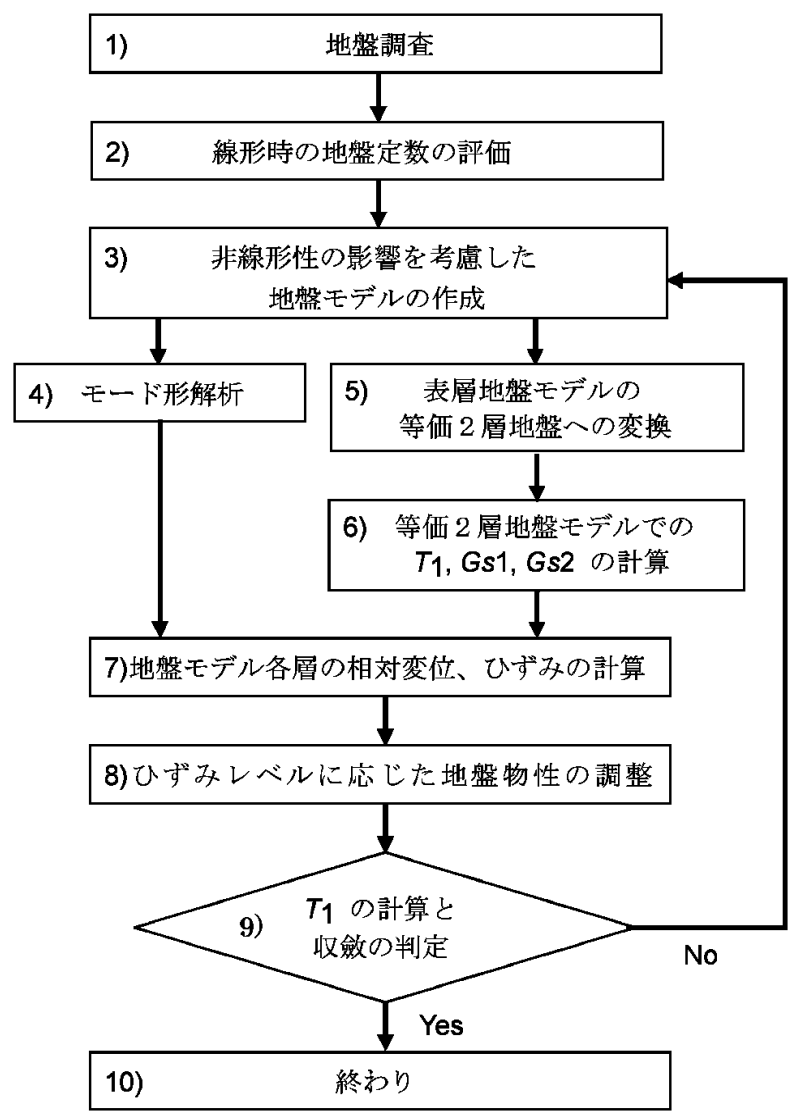

図 5 地表面加速度応答スペクトル算定のフロー
1993）で地盤を均質・不均質の 2 種類に分類して増幅 特性を定めているように，一様な方法で表現することは 困難を伴うと言える。小山ほか（2002）は，工学的基 盤を含め 3 層からなる地盤モデルをパラメトリックに 設定して, 限界耐力計算と SHAKE で求まる一次卓越 周期 $T_{1}$ とそれ対する増幅率 $G_{S 1}$ を比較することで限界 耐力計算の適用性について検討し, 表層地盤が均質に近 い地盤モデルの場合には置換した等価せ九断波速度で元 の地盤特性を表現でき, 入力地震動レベルが大きいと適 用可能な地盤モデルの範囲が狭くなることを指摘してい る。森 (2001) は, 不均質表層地盤の 2 層地盤への置 換の妥当性に加えて, 地盤の非線形化による不均質化一 の適用性，開発段階で参照された等価線形解析による検 証の妥当性, 工学的基盤の定義の曖昧さ, $G s$ 評価の 2 本立て（精算法と略算法）の是非, について指摘してい る。さらに建築主事, 設計事務所, 建設会社設計者への ヒヤリングから，限界耐力計算は理解が困難であるこ と, 認定された市販プログラムが設計に必要との意見が 多数あったことを紹介している。また標準加速度応答ス ペクトルは既往の第二種地盤における $R_{t}$ の特性をべー スに規定されており, 長周期地震動特性に影響する地下 深部構造が考慮されていないなぎ， $R_{t}$ が規定された後 に得られた知見の取り込みがなされていないうえ，川 瀬, 佐藤 (2002) が指摘しているように, 地震動の空 間変動が取り込まれていない。

これら等の問題点に対して，例えば，三浦 (2004) は, 限界耐力計算の精算法では短周期建物への入力地震 動レベルが過大であるとの議論があることを受けて, 固 有周期 $T_{1}$ の変動を $\pm 10 \%$ に狭めると同時に $G_{S}$ の下限 值を1.0に下げる表層増幅係数を提案している。林ほか （2003）は，一様な表層地盤と工学的基盤で構成される 2 層地盤を対象に, 弾性時のインピーダンス比に基づい た地盤增幅特性係数の略算式を提案している。また, 曖 昧とされる工学的基盤の設定方法として，a）インピーダ ンス比 $\alpha$ が極小となる位置とする, b) 工学的基盤を深 めに設定して最大せん断ひずみ $\gamma$ の収斂計算を行った後, $\gamma$ が急増する位置を工学的基盤と再設定して 2 層化する, 2 通りの方法を提案している。境ほか（2003）は, 収斂 計算を必要とせずに表層地盤の非線形性を考慮して地表 における加速度応答スペクトルを求める簡便な評価法を 提案している。安里ほか (2002), 佐土平ほか (2002) は, 一様な表層地盤と工学的基盤で構成される 2 層地 盤を対象に地盤特性をパラメータとして地盤をモデル化 し，1 次元波動論に基づく等価線形解析により卓越周期 と増幅率の評価を行い, 線形時 $V_{S}$ をパラメータとした $T_{1}$ と $G_{S 1}, G_{S 2}$, の推定式を提案している。川瀬, 佐藤 （2002）は，堆積盆地周辺サイトでの地震動レベルを定 義し, 堆積盆地内のサイトにおいては直下の地震基盤の 影響を考慮した盆地係数や, 堆積盆地端部の影響を考慮 するエッジ係数を提案している。 


\section{5. おわりに}

我が国の建築物は，建築基準法関係規定に従って設 計・建設される。地震動に関わる構造計算規定は, 許容 応力度等設計と限界耐力計算の 2 通りがある。この 2 通りの計算手法では，精粗は有るもののそれぞれ建築物 の建つ当該表層地盤の震動特性を取り込むことが可能で ある。特に後者の限界耐力計算は, 工学的基盤において 標準加速度応答スペクトルとして地震動が規定されてい るため, 表層地盤増幅特性をより詳細に考慮・取り込む ことが可能となっている。この計算方法を適用する場 合, 地盤の層序, 各層の単位堆積重量, せ九断波速度等 の地盤定数が必要なことから, 当該地盤における地盤情 報が整つているか, これらの情報が入手可能な地盤調査 を行う必要がある。

他方，限界耐力計算を手計算でもできるような簡略な 手法とする必要性から，地盤震動特性評価の簡略化が導 入され, 結果として手法の適用性や精度に制限が加わら ざるを得ない状況となっている。地震動のレベルに関し ても, 既往の設計用地震力との連続性を考慮するため, 第二種地盤における $R_{t}$ を地震荷重と同等のものとし て, 標準加速度応答スペクトルのレベルはそれに合わせ て規定されたため, 解放工学的基盤での地震動に関する 新たな知見が取り込まれていない。さらに近年超高層建 物など長周期構造物の地震応答問題で注目を集めてい る, 深部地盤構造に関係する周期 1 秒から 10 秒程度の やや長周期帯域の地震動特性・振幅レベルは, 工学的基 盤において地震動を規定したことと既往の地域係数をそ のまま用いていることから，高度化がなされなかつた。 また, 限界耐力計算に必要な表層地盤の定数を得るため の地盤調査は, これまでも比較的規模の大きな建物の建 設の際には地盤調査が行われているが, 地盤震動特性の 精度におよぼす地盤情報の重要性を考えると，より簡便 でありながら十分な精度の得られるような地盤調査法が 一般化することが望まれる。

現行限界耐力計算に関わるこれら課題は，これまでに 提案されている改良案や, 近年豊富に得られている地震 記録に基づいて，より合理的な設計用入力地震動を設定 できるように改善されてゆくべきものと考える。

\section{参 考 文 献}

Applied Technology Council (1978) : Tentative Provisions for the Development of Seismic Regulations for Buildings (ATC-3-06), Berkeley, Calif.

林 康裕・森井雄史 - 鬼丸貞友・吉川正隆（2003）：限界耐力 計算法における地盤増幅係数評価に関する研究，日本建築 学会構造系論文集, 第567号, pp. 41-46

飯場正紀 (2001)：限界耐力計算における入力地震動・地盤増 幅に関する技術的背景, 第29回地盤震動シンポジウム (2001), pp. 23-46

石山祐二 (1987)：応答スペクトル法によるベースシア係数に ついて, 日本建築学会大会学術講演梗概集 B 分冊, pp. 621-622

川瀬 博・佐藤智美 (2002)：地盤増幅特性の評価一研究成果 から見た現状と課題，第30回地盤震動シンポジウム (2002), pp. 25-36

国土交通省 HP（2005a）：建築基準法（http://law.e-gov.go.jp/ htmldata/S25/S25HO201.html)

国土交通省 HP (2005b) ：建築基準法施行令（http://law.egov.go.jp/htmldata/S25/S25SE338.html)

国土交通省 HP (2005c)：建設省告示第千七百九十三号（http： //wwwkt.mlit.go.jp/notice/index.html)

国土交通省 HP（2005d）：建設省告示第千四百五十七号（http： //wwwkt.mlit.go.jp/notice/index.html)

国土交通省建築研究所（2001）：改正建築基準法の構造関係規 定の技術的背景，ぎょうせい

国土交通省住宅局建築指導課，日本建築主事会議，財日本建築 センター（2001）：2001年版建築物の構造関係技術基準解 説書, 工学図書秼

小山 信・緑川光正・大川 出・飯場正紀 (2002) : 限界耐力 計算（地盤増幅）の適用範囲に関する研究，第11回日本地 震工学シンポジウム論文集, pp. 647-650

三浦賢治・古山田耕司・飯場正紀（2001）：応答スペクトル法 による表層地盤の非線形増幅特性の解析法, 日本建築学会 構造系論文集, No. 539 , pp. 57-62

三浦賢治（2004）：表層地盤の増幅，限界耐力計算の現状と課 題, 日本建築学会耐震構造性能評価検討ワーキンググルー プ報告, pp. 177-180

森伸一郎（2001）：改正建築基準法による表層地盤増幅の評価 法における諸問題, 第29回地盤震動シンポジウム (2001), pp. $67-80$

日本建築学会（1993）：建築物荷重指針・同解説，丸善 日本建築センター（1993）：設計用入力地震動作成手法指針案 佐土平淳美 - 青木博文 - 松本由香 - 池田勝利 - 安里 元 (2002)：1 次元波動論等価線形解析による表層地盤の卓越 周期と増幅率の検討 その 2 , 日本建築学会大会学術講演 梗概集，構造 B-2, pp. 241-242

境 有紀・津野靖志・工藤一嘉・壁谷澤寿海（2003）：改正建 築基準法の解放工学的基盤波を想定した表層地盤増幅特性 の簡便評価法, 日本建築学会構造系論文集, 第565号, pp. $73-78$

安里 元 - 青木博文 - 松本由香 - 佐土平淳美 - 池田勝利 （2002）：1 次元波動論等価線形解析による表層地盤の卓越 周期と増幅率の検討 その 1 , 日本建築学会大会学術講演 梗概集，構造 B-2, pp. 239-240 